\title{
73 各種木酢液・竹酢液の水生生物に対する影響と変異原性
}

○駒形 修·本山直樹 (千葉大·園)

Aquatic toxicity and mutagenicity of various pyroligneous acid formulations

Komagata, O., Motoyama, N.

特定農薬候補資材である木酢液・竹酢液のリスク評価として，水生動物に対する毒性と変 異原性について検討した。屋外の実験池に木酢液を施用し，ミジンコ，ユスリカ幼虫等の相 対密度を調査したが影響は確認できなかった。室内検定では当該木酢液のヒメダカ，ウシガ エルの幼生に対するLC50は各々 $0.27 \%$ と.25\%であり，これを酢酸濃度に換算し，純粋酢酸の LC50值と比較すると，木酢液の毒性が若干高い傾向が見られ，酢酸以外の成分にも多少毒性 があることが推察された。市販木酢液 12 種と自家製木酢液7種の原液についてumu試験により 変異原性を検定したが，抗菌活性のために評価ができなかった。また含有されている成分を 個別に試験した場合とは結果が異なり，混合物の変異原性試験が困難であることを暗示した.

\section{4 電気刺激を利用したユスリカ幼虫の駆除に関する基礎研究}

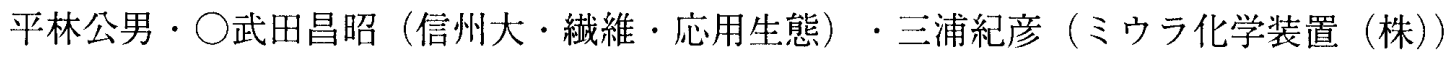

Studies on the control of chironomid larvae using the electric stimulus

Hirabayashi, K., Takeda, M., Miura, N.

ウスイロユスリカ幼虫について，その防除対策を立案する上で，化学的な防除策がとれな いケースが多々ある．特に，室内プールなどから発生する場合には，物理的な防除が中心と なる．本研究においては，比較的電気伝導度の高い水域におけるウスイロユスリカ幼虫の物 理的防除策を考案するために, 電気刺激を利用して, 発生源の防除が可能かどうかの基礎的 な実験を試みた。【実験 $1 】$ 直流 $180 \mathrm{~V}$, 通電時間：5秒, 10 秒, 15 秒, 30 秒, 45 秒, 90 秒.【実験 $2 】$ 交流 $260 \mathrm{~V}, 190 \mathrm{~Hz}$, 通電時間 : 5秒, 10 秒, 15 秒, 30秒, 45秒, 90 秒. 各実験の結果【実験 1 】【実 験 $2 】 と も に ，$ 通電時間を長くすると，死亡率は有意に上昇した。また，同電圧 $(180 \mathrm{~V})$ の場 合, 直流と交流とで比較すると, 直流の方が通電時間が長い実験区ほど死亡率が有意に高か った．以上のことより，ある一定の電気刺激をユスリカ幼虫に与えることにより，幼虫の死 亡率が上がり，ユスリカ幼虫の物理的防除対策に応用できることが示唆された。 